\title{
PHYTOTOXIC, ANTIOXIDANT, ANTIBACTERIAL, AND ANTILEISHMANIAL ACTIVITIES OF EUPHORBIA HIRTA FROM CHITWAN DISTRICT NEPAL
}

\author{
KHAGA RAJ SHARMA* \\ Central Department of Chemistry, Tribhuvan University, Kirtipur, Kathmandu, Nepal. Email: khagaraj_sharma33@yahoo.com
}

Received: 24 November 2019, Revised and Accepted: 27 December 2019

ABSTRACT

Objectives: The aim of this study is to investigate the antimicrobial, antioxidant, antileishmanial, and phytotoxic activities and estimation of total phenolic and flavonoid contents in methanol extract of Euphorbia hirta collected from Chitwan district of Nepal using in vitro studies.

Methods: Methanol extract of the plant was prepared by cold percolation method. Screening of secondary metabolites was performed by color differentiation methods. The in vitro antioxidant potential of the plant extract was evaluated by 2,2-diphenyl-1-picrylhydrazyl assay in which percentage scavenging and inhibitory concentration $\left(\mathrm{IC}_{50}\right)$ were calculated. Furthermore, antileishmanial and phytotoxic activity was evaluated by adopting the standard protocols. Phenolic and flavonoid content was estimated using Folin-Ciocalteu phenol reagent and aluminum chloride colorimetric method, respectively. The antimicrobial activity was evaluated by agar well diffusion method.

Results: The antileishmanial activity of the methanolic extract of $E$. hirta showed low leishmanicidal activity IC $68.1 \pm 1.2 \mu \mathrm{g} / \mathrm{ml}_{50}$ standard deviation (SD) as compared to the standard drugs amphotericin B $0.29 \pm 0.05 \mu \mathrm{g} / \mathrm{ml}$ SD and pentamidine $5.09 \pm 0.09 \mu \mathrm{g} / \mathrm{ml}$ SD. The radical scavenging activity shows $\mathrm{IC}_{50}=29.23 \pm 0.21 \mu \mathrm{g} / \mathrm{ml} \mathrm{SD}$ which is found potent than the standard ascorbic acid $\mathrm{IC}_{50}=45.93 \mu \mathrm{g} / \mathrm{ml}$. The extract of $E$. hirta contains high value of total phenolic content milligram gallic acid equivalent per gram (138.10 $\pm 4.90 \mathrm{mg}$ GAE$/ \mathrm{g}$ SD) and flavonoid content milligram quercetin equivalent per gram (11.54 $\pm 0.00 \mathrm{mg} \mathrm{QE} / \mathrm{g} \mathrm{SD}$ ). The plant extract exhibits weak antibacterial activity against Staphylococcus aureus (9.0 mm), Bacillus subtilis (11.0 mm), Escherichia coli $(9.0 \mathrm{~mm})$, and Salmonella Typhi $(9.0 \mathrm{~mm})$ at a concentration of $10.0 \mathrm{mg} / \mathrm{ml}$ in which $50 \mu \mathrm{l}$ was loaded per well. Plant extract exhibits moderate phytotoxic activity with the number of fronds 3,10 , and 14 against the different concentrations of plant extract.

Conclusions: The preliminary results of this study have put forward E. hirta into promising herbs with good antioxidant activities, moderate phytotoxic activity, and potential source of antibacterial agent with a significant amount of total phenolic and flavonoid contents. Although the plant extract shows the potent biological activity, further studies are needed to assess its mechanism of action.

Keywords: Euphorbia hirta, Phytotoxic, Antioxidant, Antimicrobial, Antileishmanial, Methanolic extract.

(C) 2020 The Authors. Published by Innovare Academic Sciences Pvt Ltd. This is an open access article under the CC BY license (http://creativecommons. org/licenses/by/4. 0/) DOI: http://dx.doi.org/10.22159/ajpcr.2020.v13i2.36469

\section{INTRODUCTION}

The plant Euphorbia hirta is commonly known as dudhe jhar. The plant is very frequent in rice fields, especially in Terai region of Nepal. The plant belongs to the family Euphorbiaceae. The plant has been traditionally used for the treatment of different diseases basically for skin diseases. The phytochemical screening of the methanolic extract of the stem of E. hirta revealed that the plant is the rich source of secondary metabolites. The compound teraxerol isolated from this plant showed the antiasthmatic activity carried out on histamine-induced bronchospasm in guinea pigs that significantly inhibited the contractile effect of histamine [1]

Thin-layer chromatography showed the presence of quercetin, ferulic acid, and gallic acid in flavonoid fraction of E. hirta whole plant [2]. E. hirta showed antimicrobial, antifungal, antiviral, anti-inflammatory, antiarthritic, and antioxidant effects with the presence of polyphenolic and flavonoid compounds lead to perform the wound healing activity of enriched flavonoid fraction [3]. The plant is widely used in the traditional system of medicines for the treatment of respiratory diseases, gastrointestinal disorders, tumors, lactation in women, wound healing, and urinogenital disorders. The biological activities of isolated compounds such as scopoletin, scoparone, isoscopoletin, quercetin, isorhamnetin, pinocembrin, kaempferol, luteolin, and gallic acid from the E. hirta were also studied [4]. The extract and active component showed strong inhibition in nitric oxide production that showed antidiabetic and antioxidant effects in mice [4]. Phytochemical screening of E. hirta leaf extract revealed the presence of secondary metabolites as reducing sugars, terpenoids, alkaloids, steroids, tannins, flavonoids, and phenolic compounds. The methanol extract of $E$. hirta was reported to show the potent antitumor activity [5]. The ethanol extract of E. hirta showed a significant decreased in blood glucose level on alloxan-induced diabetic rats [6]. Ethanol extract and ethyl acetate fractions of the plant had $\alpha$-glucosidase inhibition activity while n-hexane, chloroform, butanol, and water fractions had no $\alpha$-glucosidase inhibitory effect [7]. Antibacterial sensitivity test indicated that the extract of E. hirta had little or no zone of inhibition (ZOI) against Haemophilus influenzae [8]. The natural compounds quinine and Cephaelis have been used for the management of protozoan parasitic diseases, malaria, and amoebiasis. The compound holamine and hydroxyl holamine showed potent antileishmanicidal activity against $L$. donavari [9].

The present study focus on the antimicrobial, antioxidant, phytotoxic, and antileishmanial activities of the methanolic extract of E. hirta collected from Chitwan district of Nepal.

\section{MATERIALS AND METHODS}

\section{Plant materials}

The whole plants (leaves, stems, and roots) of E. hirta were collected from Chitwan district of Nepal in 2014. The plant was identified by Rita Chhetry, Research Officer, National Herbarium and Plant Resources, Ministry of Forests and Soil Conservation, Godawari, Nepal.

\section{Extraction}

The plant was washed with tap water to remove the soil and other debris, dried under shade and kept at $2{ }^{\circ} \mathrm{C}$ until extraction. The whole 
plant was powdered then weighed ( $50.0 \mathrm{~g}$ ), soaked in methanol (about $400 \mathrm{ml}$ ) for $72 \mathrm{~h}$ and filtered using Whatman No 1 filter paper. The filtrate obtained was concentrated under reduced pressure in a rotatory evaporator at $45^{\circ} \mathrm{C}$ to obtain the crude extract.

\section{Phytochemical screening}

The methanolic extracts of plant sample were analyzed for the presence of secondary metabolites such as polyphenols, alkaloids, flavonoids, tannin, carotenoids, saponins, reducing sugars, cardiac glycosides, steroids, terpenoids, glycoside, and anthraquinone by adopting the standard procedures of analysis $[10,11]$.

\section{2,2-Diphenyl-1-picrylhydrazyl (DPPH) radical scavenging assay} The free radical scavenging activity was measured using DPPH radical scavenging assay [12-14]. Different concentrations of test samples $(5,10,20,30,40,50,60,70,80,90$, and $100 \mu \mathrm{g} / \mathrm{ml})$ were prepared while the concentration of DPPH was $0.2 \mathrm{mM}$ in the reaction mixture. These reaction mixtures were taken in tubes and incubated at $37^{\circ} \mathrm{C}$ for $30 \mathrm{~min}$. Discolorations were measured at $517 \mathrm{~nm}$ using a ultraviolet (UV)-visible spectrophotometer. Percent radical scavenging activity was calculated by comparison with the methanol treated control group; ascorbic acid was used as a positive control. Measurement was performed at least in triplicate. The percentage scavenging of the DPPH free radical was calculated using the equation. The inhibition curve was plotted for the triplicate experiments and represented as the percentage of mean inhibition \pm standard deviation (SD) and the inhibitory concentration $\left(\mathrm{IC}_{50}\right.$ ) values were obtained.

\section{Total phenolic content determination}

The total phenolic content was determined using the Folin-Ciocalteu phenol reagent $0.1 \mathrm{ml}$ of each extract $(2.5 \mathrm{mg} / \mathrm{ml})$ was separately mixed with $1.0 \mathrm{ml}$ of Folin-Ciocalteu phenol reagent and $0.8 \mathrm{ml}$ of aqueous $1 \mathrm{M}$ $\mathrm{Na}_{2} \mathrm{CO}_{3}$ solution. The reaction mixture was allowed to stand for about $15 \mathrm{~min}$, and the absorbance of the reactant was measured at $765 \mathrm{~nm}$ using the UV-visible spectrophotometer. The calibration curve was constructed using the methanolic solution of gallic acid as standard with the concentration ranging from 25 to $250 \mu \mathrm{g} / \mathrm{ml}$. With the help of this calibration curve of gallic acid, the concentration of the sample was calculated. The total polyphenol content was expressed in milligrams of the gallic acid equivalent per gram of the dry mass (mg GAE/g) [15]

\section{Total flavonoid content determination}

The total flavonoid content was estimated using the aluminum chloride $\left(\mathrm{AlCl}_{3}\right)$ colorimetric method. In this method, $0.25 \mathrm{ml}$ extract $(10 \mathrm{mg} / \mathrm{ml})$ was separately mixed with the $0.75 \mathrm{ml}$ of methanol, $0.05 \mathrm{ml}$ of the $10 \%$ aluminum chloride, $0.05 \mathrm{ml}$ of the $1 \mathrm{M}$ potassium acetate $\left(\mathrm{CH}_{3} \mathrm{COOK}\right)$, and $1.4 \mathrm{ml}$ of the distilled water. The reaction mixture was allowed to stand for about $30 \mathrm{~min}$ at room temperature. The mixture was subjected to measure the absorbance at $415 \mathrm{~nm}$ in UV-visible spectrophotometer. The calibration curve was constructed with the help of standard quercetin solutions in methanol with concentration ranging from 10 to $100 \mu \mathrm{g} / \mathrm{ml}$. The total flavonoid content was expressed in milligram of quercetin equivalent per gram of the dry mass (mg QE/g) [15]

\section{Statistical analysis}

Antioxidant activity, total phenolic content, and flavonoid content reported as the mean \pm SD. A significant difference for multiple comparisons was calculated using a one-way analysis of variance. $\mathrm{p}<0.05$ was considered statistically significant.

\section{Antimicrobial activity}

The antibacterial activity of the methanol extract of $E$. hirta was tested against the test organisms by the agar well diffusion method. Sterile Muller-Hinton agar plates of approximately $6 \mathrm{~mm}$ thickness were prepared. The inoculated plates were left to dry for a few minutes at room temperature with the lid closed. Five different wells were made in the inoculated media plates with the help of sterile cork borer no. 6 and labeled properly. Hence, the diameter of a well was $6 \mathrm{~mm}$. Then, $50 \mu \mathrm{l}$ of the plant extract was introduced into the respective well. In one well pure methanol was filled as a negative control. The plates were then left for $1 / 2 \mathrm{~h}$ with the lid closed so that the extract diffused into media. The plate was incubated overnight at $37^{\circ} \mathrm{C}$. After proper incubation (18-24 h), the plates were observed for the ZOI around well.

\section{In vitro phytotoxic bioassay}

The phytotoxic bioassay was performed by adopting the standard protocol in which E-Medium was prepared by mixing various constituents in $1000 \mathrm{ml}$ distilled water, and $\mathrm{pH}$ was adjusted between 6.0 and 7.0 by adding potassium hydroxide pellets. Plant growth inhibitors and promoters serving as negative and positive controls, respectively. The number of fronds was counted and recorded per flasks on day 7. Results were analyzed as growth percent with reference to the negative control $[16,17]$.

Percent regulation $=100-\frac{\text { Numberof fronds in test }}{\text { Numberof fronds in negative control }} * 100$

\section{Leishmanicidal assay}

Leishmanicidal assay was performed by adopting the standard protocol in which Leishmania promastigotes were grown in bulk early in modified Novy-MacNeal-Nicolle biphasic medium using normal physiological saline. Leishmania parasite promastigotes were cultured with RPMI 1640 medium supplemented with $10 \%$ heat-inactivated fetal calf serum. The plate was incubated at $22-25^{\circ} \mathrm{C}$ for $72 \mathrm{~h}$. The culture was examined microscopically and $\mathrm{IC}_{50}$ values of fractions possessing antileishmanial activity were calculated $[18,19]$.

\section{RESULTS AND DISCUSSION}

\section{Phytochemical analysis}

The result of phytochemical screening is presented in Table 1. Plant extract of $E$. hirta showed a good source of secondary metabolites such as flavonoids, terpenoids, polyphenols, glycosides, reducing sugars, cardiac glycosides, anthraquinone, carotenoids, and saponin. It shows that the plant extract can be used to isolate the active compounds for different biological activities.

The plant extracts containing secondary metabolites are known to be biologically active and, therefore, aid the antimicrobial activities through a different mechanism.

\section{Antimicrobial activity}

The result of antimicrobial activity is shown in Table 2 . The plant extract is the rich source of secondary metabolite with mild antibacterial activity against Gram-positive and Gram-negative organisms. The plant extract possess weak antibacterial effects against Gram-positive bacteria Staphylococcus aureus $(9.0 \mathrm{~mm})$ and Bacillus subtilis $(11.0 \mathrm{~mm})$ and Gram-negative bacteria Escherichia coli $(9.0 \mathrm{~mm})$ and Salmonella Typhi $(9.0 \mathrm{~mm})$ at a concentration of $10.0 \mathrm{mg} / \mathrm{ml}$ in which $50 \mu \mathrm{l}$ was loaded per well. Plant extract revealed the most significant antibacterial activity and broad antimicrobial spectrum against the strains of S. aureus, Acinetobacter baumannii, and Pseudomonas aeruginosa, with moderate zones of inhibition $26.00 \mathrm{~mm}, 20.33 \mathrm{~mm}$, and $17.00 \mathrm{~mm}$, respectively. The ethyl acetate extract presented a slightly lower antimicrobial activity than the ether extract [20].

\section{Phytotoxic activity}

Plant extract exhibits moderate phytotoxic activity with the number of fronds 3,10 , and 14 against the concentration of 1000, 100, and

Table 1: Phytochemical analysis of plant extract

\begin{tabular}{llll}
\hline Polyphenols & + & Reducing sugar & - \\
Steroids & - & Tanning & - \\
Alkaloids & - & Cardiac glycoside & - \\
Flavonoids & + & Anthraquinone & + \\
Terpenoids & - & Carotenoids & + \\
Glycosides & - & Saponin & - \\
\hline
\end{tabular}

+: Presence, -: Absence 
Table 2: Antimicrobial activity of plant extract

\begin{tabular}{llllll}
\hline Plant extract & Concentration & Staphylococcus aureus & ZOI, mm & & \\
\cline { 4 - 6 } & & & Bacillus subtilis & Salmonella Typhi & Escherichia coli \\
\hline Euphorbia hirta & $10 \mathrm{mg} / \mathrm{ml}$ & 9 & 11 & 9 & 9 \\
& $15 \mathrm{mg} / \mathrm{ml}$ & 9 & 11 & 9 & 9 \\
& $20 \mathrm{mg} / \mathrm{ml}$ & 10 & 12 & 10 & 10 \\
\hline
\end{tabular}

ZOI: Zone of inhibition

Table 3: In vitro phytotoxic activity

\begin{tabular}{|c|c|c|c|c|c|}
\hline \multirow[t]{2}{*}{ Name of the plant } & \multirow{2}{*}{$\begin{array}{l}\text { Concentration of plant extract } \\
(\mu \mathrm{g} / \mathrm{ml})\end{array}$} & \multicolumn{2}{|c|}{ No of fronds } & \multirow{2}{*}{$\begin{array}{l}\text { \% growth } \\
\text { regulation }\end{array}$} & \multirow{2}{*}{$\begin{array}{l}\text { Concentration of standard } \\
\text { drug }(\mu \mathrm{g} / \mathrm{ml})\end{array}$} \\
\hline & & Sample & Control & & \\
\hline \multirow[t]{3}{*}{ Lemna minor } & 1000 & 3 & 20 & 85 & 0.015 \\
\hline & 100 & 10 & & 50 & \\
\hline & 10 & 14 & & 30 & \\
\hline
\end{tabular}

Standard drug paraquat, incubation condition $=\left(28 \pm 1^{\circ} \mathrm{C}\right)$

Table 4: Antileishmanial activity

\begin{tabular}{ll}
\hline Leishmanicidal activity & IC $_{50}(\mu \mathrm{g} / \mathbf{m l}) \pm \mathbf{S D}$ \\
\hline Test compound (plant extract) & $68.1 \pm 1.2$ \\
Standard drugs & \\
$\quad$ Amphotericin B & $0.29 \pm 0.05$ \\
Pentamidine & $5.09 \pm 0.09$ \\
\hline Incubation period $72 \mathrm{~h}$, incubation temperature $22^{\circ} \mathrm{C} . \mathrm{IC}_{50}:$ Inhibitory \\
concentration, SD: Standard deviation
\end{tabular}

Table 5: DPPH scavenging ( IC $_{50}$ ) value, total flavonoid, and phenolic content

\begin{tabular}{ll}
\hline Total flavonoid content & $11.54 \pm 0.00 \mathrm{mg} \mathrm{QE} / \mathrm{g} \mathrm{SD}$ \\
Total phenolic content & $138.10 \pm 4.90 \mathrm{mg} \mathrm{GAE} / \mathrm{g} \mathrm{SD}$ \\
DPPH scavenging $\left(\mathrm{IC}_{50}\right)$ & $29.23 \pm 0.21 \mu \mathrm{g} / \mathrm{ml} \mathrm{SD}$ \\
\hline DPPH: 2,2-diphenyl-1-picrylhydrazyl, $\mathrm{IC}_{50}$ : Inhibitory concentration, \\
SD: Standard deviation
\end{tabular}

SD: Standard deviation

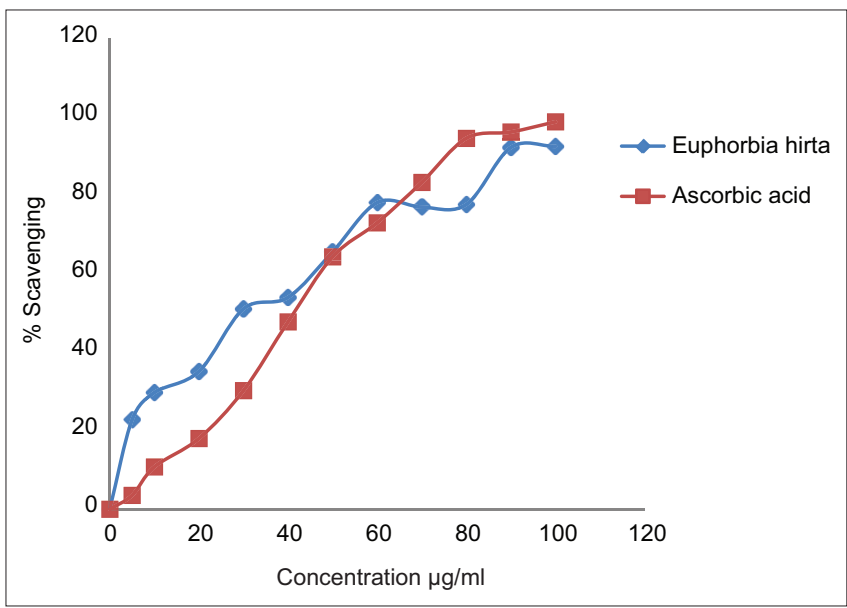

Fig. 1: Percentage scavenging of 2,2-diphenyl-1-picrylhydrazyl free radical of Euphorbia hirta and ascorbic acid

$10 \mu \mathrm{g} / \mathrm{ml}$ whereas the standard drug paraquat has 20 fronds at a concentration of $0.015 \mu \mathrm{g} / \mathrm{ml}$. The moderate phytotoxic activity was found in the $100 \mu \mathrm{g} / \mathrm{ml}$ (50\% inhibition). Significant phytotoxicity was shown in 100 and $1000 \mu \mathrm{g} / \mathrm{ml}$ with $50 \%$ and $85 \%$ growth inhibition (Table 3). The result obtained in this study was found comparable to the previously reported results where the phytotoxicity of the investigated samples on Lemna minor was detected in the $\mathrm{n}$-hexane fraction with
$12.5 \%$ and $18.7 \%$ inhibition at 10 and $100 \mu \mathrm{g} / \mathrm{ml}$, respectively. Moderate phytotoxic activity detected in the methanol extract (40.0\% inhibition) at $1000 \mu \mathrm{g} / \mathrm{ml}$. Good phytotoxic activity was detected in the chloroform fraction (68.7\% inhibition) at $100 \mu \mathrm{g} / \mathrm{ml}$ and n-butanol fraction $(62.6 \%$ inhibition) at $1000 \mu \mathrm{g} / \mathrm{ml}[21]$.

\section{Antileishmanial activity}

The results of antileishmanial activity are shown in Table 4. The methanolic extract of $E$. hirta showed moderate antileishmanial activity with $\mathrm{IC}_{50} 68.1 \pm 1.2 \mathrm{SD}$ as compared to the standard drugs. The result found comparable to the previously reported in which the aqueous extract of the stem bark of Enantia chlorantha gave a powerful effect with an $\mathrm{IC}_{50} 10.08 \mu \mathrm{g} / \mathrm{ml}$ [22]. Antileishmanial activity of aqueous and methanol extract of Aloe nyeriensis leaves against Leishmania major showed moderate activity with percent mortality $53.30 \pm 5.10$ and $68.40 \pm 6.30$ in concentration $1 \mathrm{mg} / \mathrm{ml}$, respectively [23]. These difference results of the antileishmanial activity could be attributed to the chemical composition of plants by active molecules such as phenols, flavonoids, and terpenes.

\section{Antioxidant activity}

The result of antioxidant activity is shown in Fig. 1 and Table 5 . Antioxidant minimizes the oxidative stress by scavenging the free radicals inhibiting lipid peroxidation. Antioxidants terminate the chain reaction by converting the unpaired electrons to paired ones. The concentration-dependent inhibition of DPPH free radical indicates that plant extract causes a reduction of DPPH radical in a quantitative weight relation manner. The plant extract of E. hirta was found as the source of potent antioxidants with the strongest DPPH radical scavenging activity $\left(\mathrm{IC}_{50}=29.23 \pm 0.21 \mu \mathrm{g} / \mathrm{ml} \mathrm{SD}\right)$ whereas standard ascorbic acid has $\mathrm{IC}_{50}$ of $45.93 \mu \mathrm{g} / \mathrm{ml}$. The result of the antioxidant activity of this plant extract found comparable to Nauplius graveolens, Picris asplenioides, Reichardia tingitana, and Urospermum picroides with radical scavenging activity $14.3 \%, 6.25 \%, 7.73 \%$, and $4.14 \%$, respectively [24].

The result showed significant total phenolic and flavonoid content in the plant extract. The extract of $E$. hirta contains high value of phenolic $(138.10 \pm 4.90 \mathrm{mg} \mathrm{GAE} / \mathrm{g} \mathrm{SD})$ and flavonoid content $(11.54 \pm 0.00 \mathrm{mg}$ QE/g SD) exhibited the greatest antioxidant activity.

\section{CONCLUSIONS}

From this study, it is concluded that the plant extracts are the potent source of phytoconstituents and could be used for the isolation of active natural compounds. The susceptibility of various microbial agents to different concentration of plant extract indicated that plant is the potential source for the antimicrobial compound. DPPH scavenging activity showed that the methanol extract is the potent source of antioxidant natural 
compounds with IC $29.23 \pm 0.21 \mu \mathrm{g} / \mathrm{ml} \mathrm{SD}$ with respect to the standard ascorbic acid IC $\mathrm{C}_{50} 45.93 \mu \mathrm{g} / \mathrm{ml}$. Phenolic and flavonoids have been reported to be associated with antioxidant action in the biological system, acting as scavengers of singlet oxygen and free radicals. The plant extract showed moderate phytotoxic activity $85 \%, 50 \%$, and $30 \%$ growth regulation with the number of fronds 3,10 , and 14 , respectively, which is lower than the standard drug paraquat with the number of fronds 20 at a concentration of $0.015 \mu \mathrm{g} / \mathrm{ml}$. Methanolic extracts of E. hirta showed moderate phytotoxic activity. The plant extract showed weak leishmanicidal activity $68.1 \pm 1.2 \mu \mathrm{g} / \mathrm{ml} \mathrm{SD}$ against $L$. major. Plant extract showed mild activity against Gram-positive and Gram-negative bacteria. The plant extract was found a rich source of total phenolic and flavonoid content.

\section{ACKNOWLEDGMENTS}

The author is thankful to National Herbarium and Plant Resources, Ministry of Forests and Soil Conservation, Godawari, for identification of plant and thankful to the Central Department of Chemistry and Biotechnology, Tribhuvan University, for laboratory facilities.

\section{AUTHOR'S CONTRIBUTIONS}

The author declares that this work done by the author mentioned in this article.

\section{CONFLICTS OF INTEREST}

There are no conflicts of interest the author alone responsible for the content and writing of this manuscript.

\section{AUTHOR'S FUNDING}

The author himself bears the publication fees of this paper

\section{REFERENCES}

1. Saxena P, Tiwari P. $13 \alpha$-methyl-27-norolean-14-en-3 $\beta$-ol, atriterpene isolated from the stem of Euphorbia hirta Linn. Possess an antiasthmatic properties. Res J Chem Sci 2014;4:21-6.

2. Bigoniya P, Agrawal S, Verma NK. Potential wound healing activity of Euphorbia hirta Linn total flavonoid fraction. Int J Pharm Sci Rev Res 2013;22:149-56

3. Ping KY, Darah I, Chen Y, Sasidharan S. Cytotoxicity and genotoxicity assessment of Euphorbia hirta in MCF-7 cell line model using comet assay. Asian Pac J Trop Biomed 2013;3:692-6.

4. Kumar S, Malhotra R, Kumar D. Antidiabetic and free radicals scavenging potential of Euphorbia hirta flower extract. Indian J Pharm Sci 2010;72:533-7

5. Patil SB, Magdum CK. Phytochemical investigation and antitumour activity of Euphorbia hirta Linn. Eur J Exp Biol 2011;1:51-6.

6. Uppal G, Nigam V, Kumar A. Antidiabetic activity of ethanolic extract of Euphorbia hirta Linn. Pharm Lett 2012;4:1155-61.
7. Widharna RM, Soemardji AA, Wirasatisna KR, Kardono LB. Antidiabetes mellitus activity in vivo of ethanolic extract and ethyl acetate fraction of Euphorbia hirta Linn. Herb. Int J Pharm 2010;6:231-40

8. Kareem KT, Ezen AR, Christiana OC, Kehinde ER, Ombolaji JN, Olajid AJ. In vitro antimicrobial activities of Euphorbia hirta against some clinical isolates. Agric Biol J North Am 2012;3:169-74.

9. Wright CW, Phillipson JD. Natural products and the development of selective antiprotozoal drugs. Phytother Res 1990;4:127-39.

10. Dabur R, Gupta A, Mandal TK, Singh DD, Bajpai V, Gurav AM, et al. Antimicrobial activity of some Indian medicinal plants. Afr J Tradit Complement Altern Med 2007;4:313-8.

11. Khan I, Surya RS, Surekha D, Srujana DG, Hemasundara A. Phytochemical studies and screening of leaf extracts of Azadirachta indica for its antimicrobial activity against dental pathogens. Arch Appl Sci Res 2010;2:246-50.

12. Subedi L, Timalsena S, Duwadi P, Thapa R, Paudel A, Parajuli K. Antioxidant activity and phenol and flavonoid contents of eight medicinal plants from Western Nepal. J Tradit Chin Med 2014;34:584-90.

13. Maharjan B, Baral B. Antioxidant capacity and phenolic content of some Nepalese medicinal plants. Am J Plant Sci 2013;4:1660-5.

14. Subedi A, Shrestha M, Mishra SK, Pokharel BM. Antioxidant and antibacterial activity of methanolicextract of Machilus odoratissima. J Sci Eng Technol 2012;8:73-80

15. Zhou D, Ruan J, Cai Y, Xiong Z, Fu W, Wei A. Antioxidant and hepatoprotective activity of ethanol extract of Arachniodes exilis (Hance) Ching. J Ethnopharmacol 2010;129:232-7.

16. Rehman AU. Studies in Natural Product Chemistry. Netherlands: Elsevier Science Publishers; 1991. p. 383-409.

17. Hideji Y, Oshida A, Ikuta H, Inatom T. Phenolic plant growth inhibitors from the flowers of Cucurbita pepo. Phytochemistry 1982;21:1935-7.

18. Choudhary MI, Yousaf S, Ahmed S, Samreen, Yasmeen K, Atta-urRahman. Antileishmanial physalins from Physalis minima. Chem Biodivers 2005;2:1164-73.

19. Habtemariam S. In vitro antileishmanial effects of antibacterial diterpenes from two Ethiopian Premna species: P. schimperi and P. oligotricha. Biomed Cent Pharmacol 2003;3:1-6.

20. Su PW, Yang CH, Yang JF, Su PY, Chuang LY. Antibacterial activities and antibacterial mechanism of Polygonum cuspidatum extracts against nosocomial drug-resistant pathogens. Molecules 2015;20:11119-30.

21. Fatma A, Nurgün K, Hayri D, Bilge S, Choudhary MI. Cytotoxic, phytotoxic and insecticidal activities of Chrysophthalmum montanum (DC.) Boiss. Turk J Pharm Sci 2017;14:290-3.

22. Muganza DM, Fruth BI, Lami JN, Mesia GK, Kambu OK, Tona GL, et al. In vitro antiprotozoal and cytotoxic activity of 33 ethonopharmacologically selected medicinal plants from Democratic Republic of Congo. J Ethnopharmacol 2012;141:301-8.

23. Kigondu EV, Rukunga GM, Keriko JM, Tonui WK, Gathirwa JW, Kirira PG, et al. Anti-parasitic activity and cytotoxicity of selected medicinal plants from Kenya. J Ethnopharmacol 2009;123:504-9.

24. El-Amier YA, Abbas MA. Phytotoxic effect of plant extracts from Asteraceae on germination and growth of Echinochloa crus-galli. Int J Dev Res 2015;5:4926-31 